\title{
Metamorphism and thrust tectonics in the Munsiari Group of Central Crystalline Zone of Garhwal Himalaya, India
}

\author{
S.P. Singh ${ }^{1}$, V.K. Singh ${ }^{2}$ and P.S. Saklani ${ }^{2}$ \\ 'Department of Geology, HNB Garhwal University, Srinagar (Garhwal) 246174 (UP), India \\ ${ }^{2}$ Department of Geology, University of Delhi, Delhi 110007, India
}

ABSTRACT

The Munsiari Group of the Central Crystalline Zone of Garhwal Himalaya comprises low to medium grade metamorphics of pelitic and psammitic rocks along with granitoids and gneisses. The textural and structural studies indicate that these rocks witnessed two strong tectonothermal metamorphic episodes $\left(\mathrm{M}_{1}\right.$ and $\left.\mathrm{M}_{2}\right)$. The allochthonous rocks of the $\mathrm{M}_{1}$ metamorphic episode are highly deformed and had undergone Tertiary intracontinental shortening and superposed metamorphism. The crystallisation, possibly initiated during the $\mathrm{D}_{1}$ deformation phase, continued upto the $\mathrm{D}_{2}$ deformation and biotite-chlorite (Bio-Chl), garnet-chlorite (Gt-Chl) and kyanite-staurolite (Ky-St) zones were developed. The porphyritic granitoids were emplaced at the end phase of the $M_{1}$ metamorphism. The $M_{2}$ phase of metamorphism occurred discordant to the $M_{1}$ episod and was mainly confined to the shears and are syntectonic to the movement of the Main Central Thrust. The P-T conditions inferred that metamorphism for the $\mathrm{M}_{1}$ episode took place at $400-600{ }^{\circ} \mathrm{C} / 4-6 \mathrm{Kbar}$ and at $300-500{ }^{\circ} \mathrm{C} / 4-5 \mathrm{Kbar}$ for the $\mathrm{M}_{2}$ episode.

\section{INTRODUCTION}

In Garhwal Himalaya, scanty work has been carried out on the tectonics and metamorphism of different parts (Valdiya, 1980; Gansser, 1981; Hodges et al., 1988; Sinha, 1989; Thakur, 1992; Saklani, 1993; Metcalfe, 1993 and many others). The tectonic history reveals that the Main Central Thrust (MCT) is major dislocation plane along which the rocks of the Central Crystalline Zone $(\mathrm{CCZ})$ were brought over the Proterozoic sedimentary rocks of the Lesser Himalaya (Fig. 1) from a deeper level during the Tertiary time (Heim and Gansser, 1939). It is also established that the MCT has composite thrust geometry evolved in the subsequent events of Tertiary deformation (Saklani, 1993).

The petrological studies (Valdiya and Goel, 1983; Islam and Thakur, 1988; Hodges et al., 1988; Singh et al., 1996 and 1997) reveal that the CCZ (Fig. 1) is a polyphase metamorphosed terrain, which represents medium to high grade metamorphics of pelites, psammites and carbonates along with the intrusives of granitioids of different ages (Le Fort et al., 1986; Singh et al., 1986 and Ravishanker et al., 1995). Das and Pande (1973), Valdiya (1980), Gupta (1987) and others suggested medium grade metamorphism for Munsiari and equivalent rocks. Significant data have been generated for the determination of age of metamorphism as well as igneous intrusions (Trivedi et al., 1984; Bhattacharya et al., 1984; Singh et al., 1986; Le Fort et al., 1986; Sinha, 1989 and Thakur, 1992).

The compilation of the geochronological data shows four strong thermal events in the CCZ (Singh et al., 1997) where the Munsiari Group containing medium grade metamorphics are considered as the oldest records of the CCZ. So, in the light of new geochronological data and the lack of time relationship between deformation and crystallisation, the concept of the metamorphism in Garhwal Himalaya terrain is controversial. In this paper, deformation and metamorphic history of the Munsiari Group has been discussed and an attempt has been made to distinguish between the Precambrian and Tertiary deformation and metamorphism. 


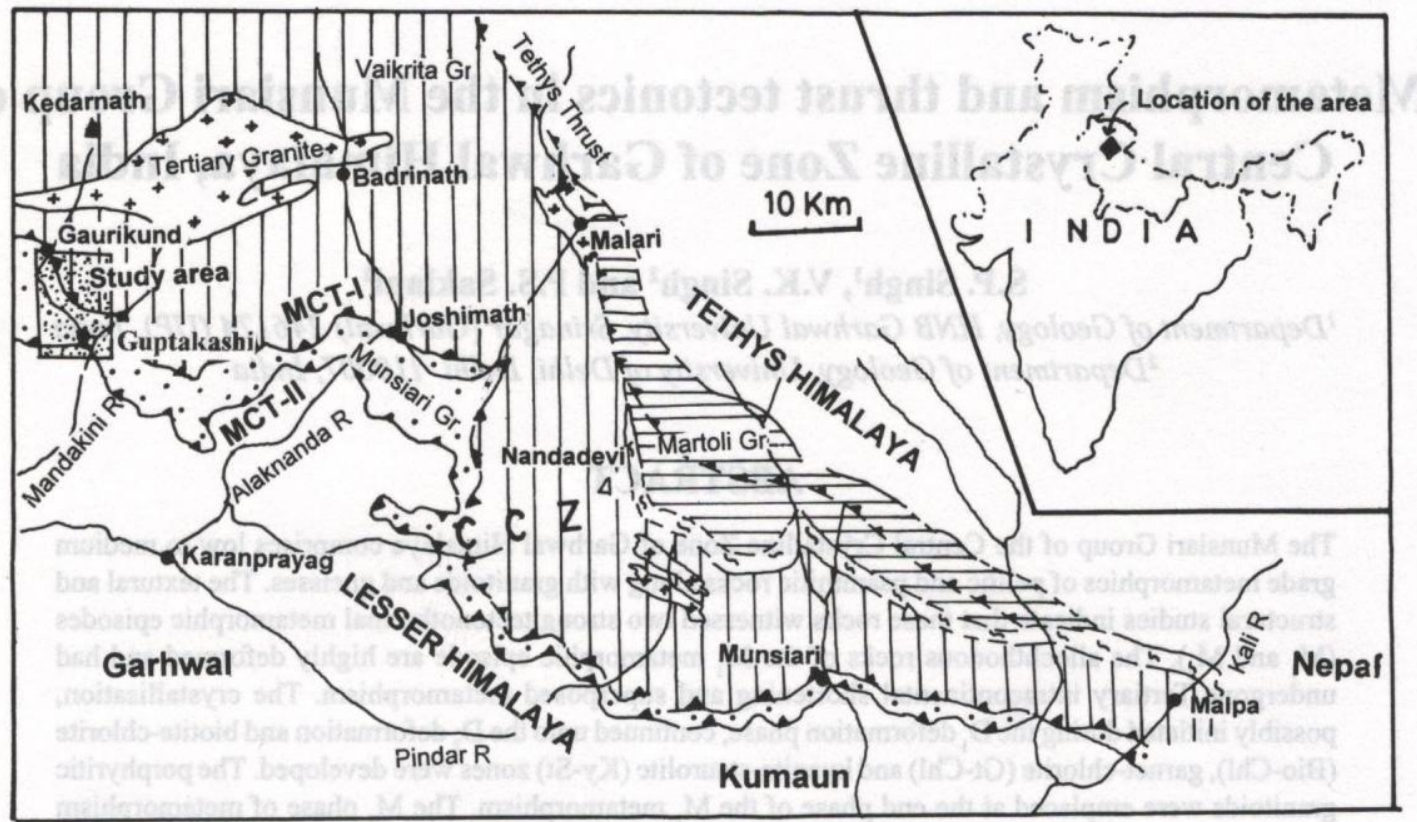

Fig. 1: General tectonic map of Garhwal Himalaya after Valdiya (1981).

\section{GEOLOGICAL SETTING}

Approaching from north to south toward the Indian plate, the Himalayan folded belt is divided into Higher Himalaya (Tethys sequences and Central Crystalline Zone), Lesser Himalaya (Zone of autochthonous and parautochthonous) and Outer Himalaya (Tertiary foredeep basin). The southern boundary of the CCZ is delineated along the MCT by the sedimentary rocks of Proterozoic age, while the northern boundary is separated from the Tethys sequences by the Himadri Thrust (Valdiya, 1987).

The CCZ of Garhwal Himalaya is divided into the Vaikrita, Munsiari and Bhatwari groups (Valdiya, 1980) delineated by MCT-I, MCT-II and MCT-III, respectively (Saklani, 1993 and Singh et al., 1996). The Vaikrita Group occurs at the northern part of the $\mathrm{CCZ}$ and contains rocks of greenschist to amphibolite facies of pelitic, psammitic and carbonate (Singh et al., 1997). The Munsiari Group occurs at the footwall of the MCT-I and is comprised of migmatites, biotite gneisses, streaky gneisses, kyanite-garnet schists, and sillimanite-kyaniteandalusite schists, garnet-mica schists, diopsidewollastonite calc-silicates along with two phases of intrusive granitoids (Singh et al., 1994 and 1996).
The Bhatwari Group is characterised by very low grade metamorphism, and occurs at the southern part of the CCZ. It locally contains garnet-mica schist, kyanite-chlorite schists, staurolite-kyanite schists, around the porphyritic biotite-granitoid at Mukhem in the Lesser Himalaya (Saklani, 1993).

\section{MANDAKINI RIVER SECTION}

In this section (Fig. 2), the Bhatwari and Munsiari groups are widely exposed (Jangpangi and Phukan, 1975; Sinha and Bisht, 1986). The rocks of the Bhatwari Group are exposed between Tilwara and Banswara (Fuchs and Sinha, 1978). The boundary of this unit is delineated by quartzites of the Garhwal Group, $1.5 \mathrm{~km}$ south of Tilwara (downstream), and is known as Alaknanda thrust (Kumar and Agarwal, 1975; Srivastava and Ahmed, 1979; Rawat and Varadrajan, 1979 and our MCT-III). Lithologically, the Bhatwari Group comprises of phyllites, slates, carbonaceous slate, phyllitic slate, quartzites and gritty quartzites. Small plutons of biotite-granite with poorly developed contact metamorphic aureole have been noticed at several places in the Bhatwari Group. The rocks between Banswara and Gaurikund represent a major thrust-sheet of the Munsiari Group 


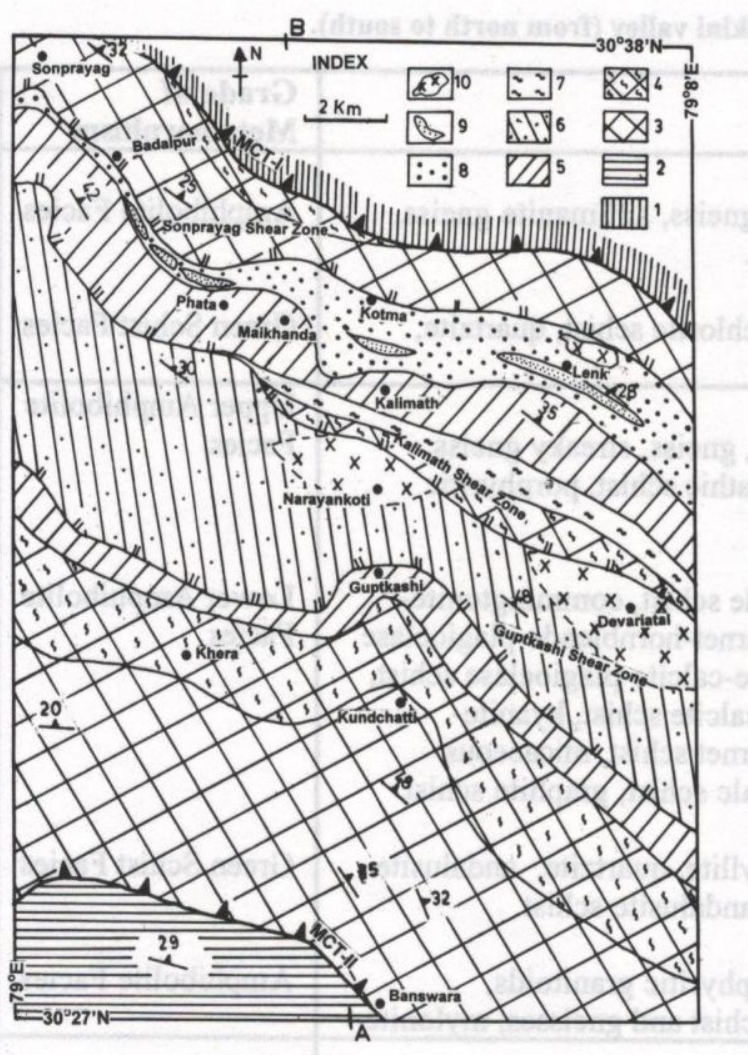

Fig. 2: General Geological map of study area in the Mandakini valley, Garhwal Himalaya. Legend: 1Vaikrita Group; 2- Bhatwari Group and 3-10: Munsiari Group, 3- Foliated granite-gneiss and mylonite; 4- Quartzofeldspathic schist and gneiss; 5Garnet-mica schist; 6- Slate, phyllite, chlorite schist, quartzite and metabasics; 7- Kyanite \pm Staurolite schist and commingtonite-hornblende schist, 8- Quartzite and micaceous quartzite; 9- calc-schist, marble and graphite schist; 10- Porphyritic biotite-granite as intrusive). A-B points for cross-section for Fig. 3 .

(Fig. 2), which comprises repeated sequences of arenaceous-argillaceous metasediments and porphyritic granitoids characterised by numerous shears ranging from few $\mathrm{cm}$ to few $\mathrm{m}$ in thickness. Lensoidal pelitic, basic and carbonate xenoblasts occur in the granitoids. Medium grade metamorphics are mainly confined in the northern parts. The middle portion of this shear zone is characterised by very low grade metamorphics, viz. slates, phyllites, metabasics, etc. The thick shear zones noticed near the MCT-II are of brittle-ductile origin, while thin shears containing silcified randomly present quartz veins are of ductile-brittle to brittle origin. The porphyroclasts of garnet and feldspar of granitegneisses usually show the simple asymmetrical shears showing southward vergence. On the basis of the grade of metamorphism and structural discontinuity, the giant thrust sheet of the Munsiari Group has been divided into different splays or duplexes (Table 1 and Fig. 3).

\section{Kundchatti Splay}

This splay contains granite-gneiss, migmatite, quartzofeldspathic schist and thick shear zones of ductile/brittle-ductile type. The andalusite-chloritemuscovite schist, muscovite-biotite schist and chlorite-biotite-sericite schist are confined to the shear zones.

\section{Guptkashi Splay}

It includes low grade metamorphic rocks of pelitic, psammitic and basic compasitions. The metabasics occasionally have amygdules. The textural study indicates that biotite, muscovite, chlorite and epidote present in the pelitic and actinolite, calcite, hornblende occur in the basic rocks initiated crystallisation in the synkinematic phase of the $\mathrm{D}_{1}$ deformation (Fig. $4 \mathrm{a}$ ) and they continued to grow even after the $\mathrm{D}_{2}$ deformation. The texture suggests that garnet initiated the crystallisation at the late stage of $D_{1}$ and continued to $D_{2}$ (Fig. 4b). The important mineral parageneses of prograde event of this unit are represented in AFM and AKF projections (Fig. 3).

The shears of this splay vary from $20 \mathrm{~cm}$ to 200 $\mathrm{m}$, and are found randomly at several places. The textural studies of rocks of S-C fabrics/shear zones show interesting results about their deformation and crystallisation history. The presence of chlorite, biotite, andalusite along the shear planes points to the conclusion that low grade metamorphic conditions prevailed during the $\mathrm{D}_{3}$ deformation or during the development of S-C fabrics. These shear zones were possibly developed in brittle-ductile conditions during the $\mathrm{D}_{3}$ deformation, which correspond to the Himalayan trend as well as of the MCT. So a syntectonic thermal episode along the shears can not be ruled out. 
S.P. Singh et al.

Table 1: Lithology and tectonic succession along Mandakini valley (from north to south).

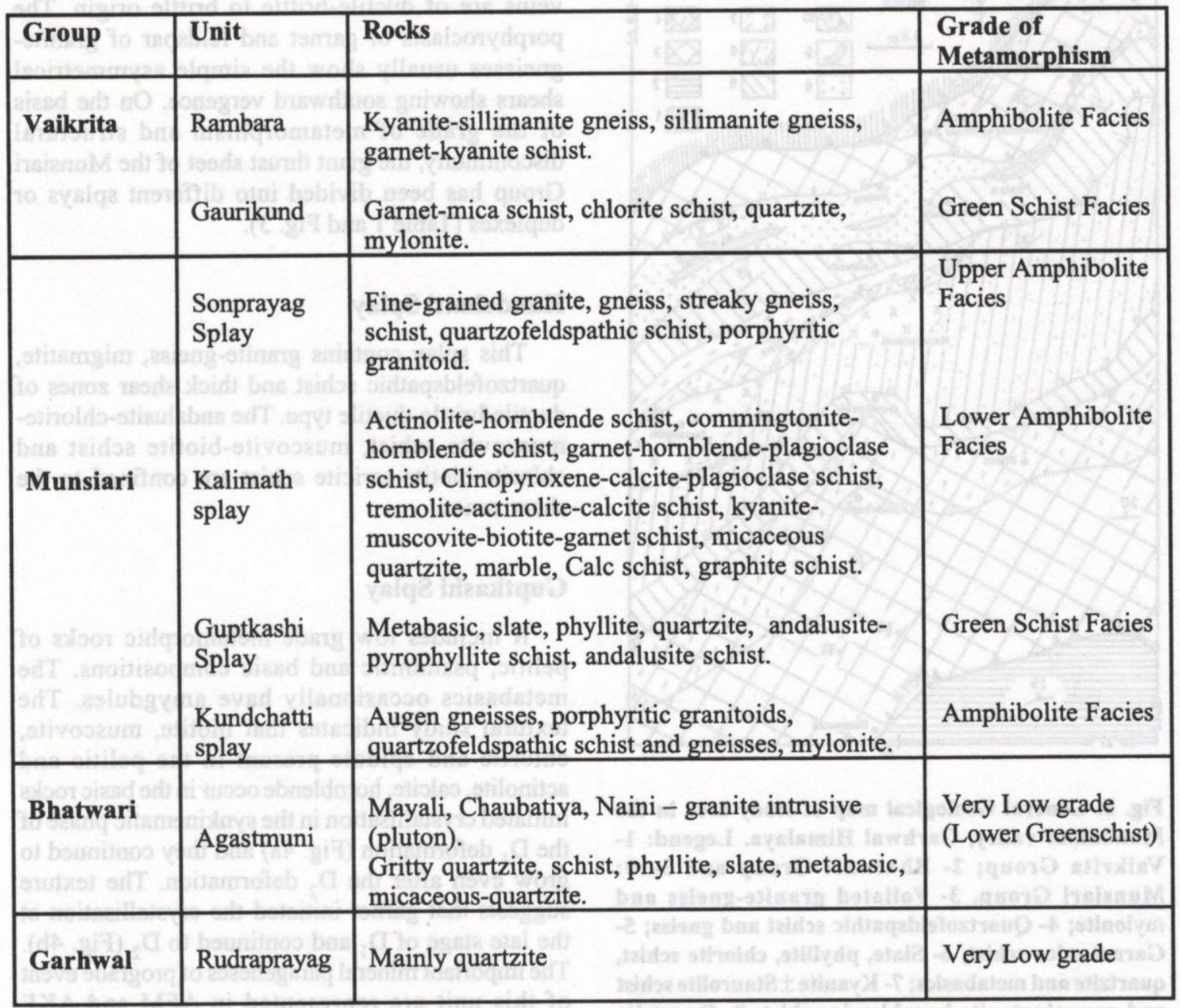

\section{Kalimath Splay}

The northern part of this splay contains a thick sequence of arenaceous, enclaves of calc-silicates and rarely the pelitic rocks while thick argillaceous and basic rocks are characterised to the southern part. On the basis of texture and mineral parageneses, three metamorphic zones have been identified in this splay.

\section{Chlorite-Biotite Zone}

Petrographic study shows that muscovite, chlorite, fuschite, microcline, etc. crystallised along the $S_{1}$ schistosity. The prograde biotite texture defined by following reactions in KFMASH system suggests the beginning of biotite zone in the argilloarenaceous rocks.

$$
\mathrm{Mus}_{1}+\mathrm{Chl}=\mathrm{Bio}+\mathrm{Mus}_{2}+\mathrm{Qtz}+\mathrm{H}_{2} \mathrm{O}
$$

\section{Garnet-Chlorite Zone}

Texturally, the grains of this zone are coarser than the chlorite-biotite (Chl-Bio) zone. The occurrence of chlorite-garnet-biotite-muscovite assemblage from the pelitic rocks marks the beginnings of the almandine zone of the greenschist facies (Fig. 4c). This reaction boundary has been marked at villages Maikhanda and Kalimath (Fig. 2) where all the 
Metamorphism and thrust tectonics in Munsiari Group of CCZ of Garhwal Himalaya, India

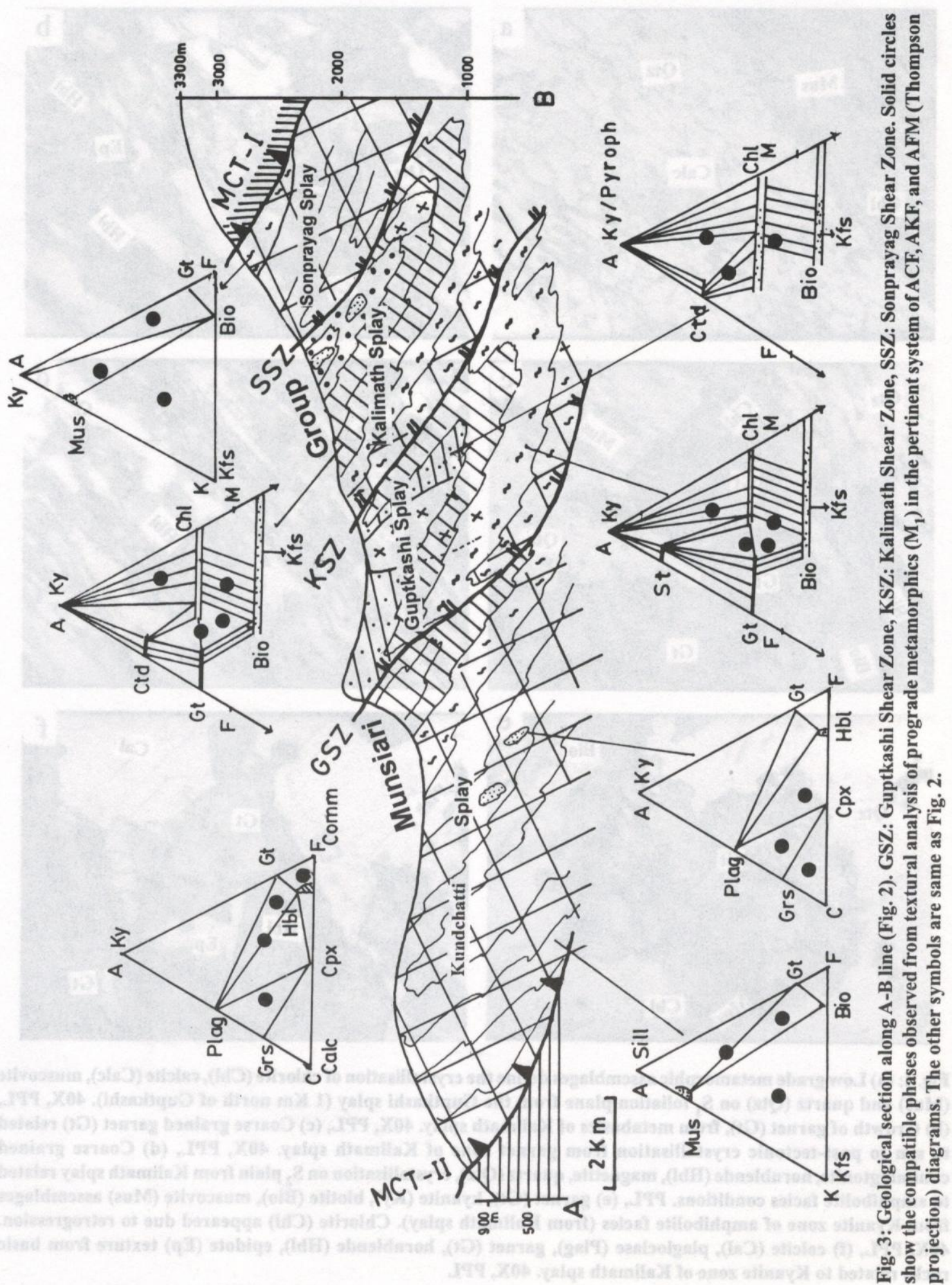




\section{S.P. Singh et al.}
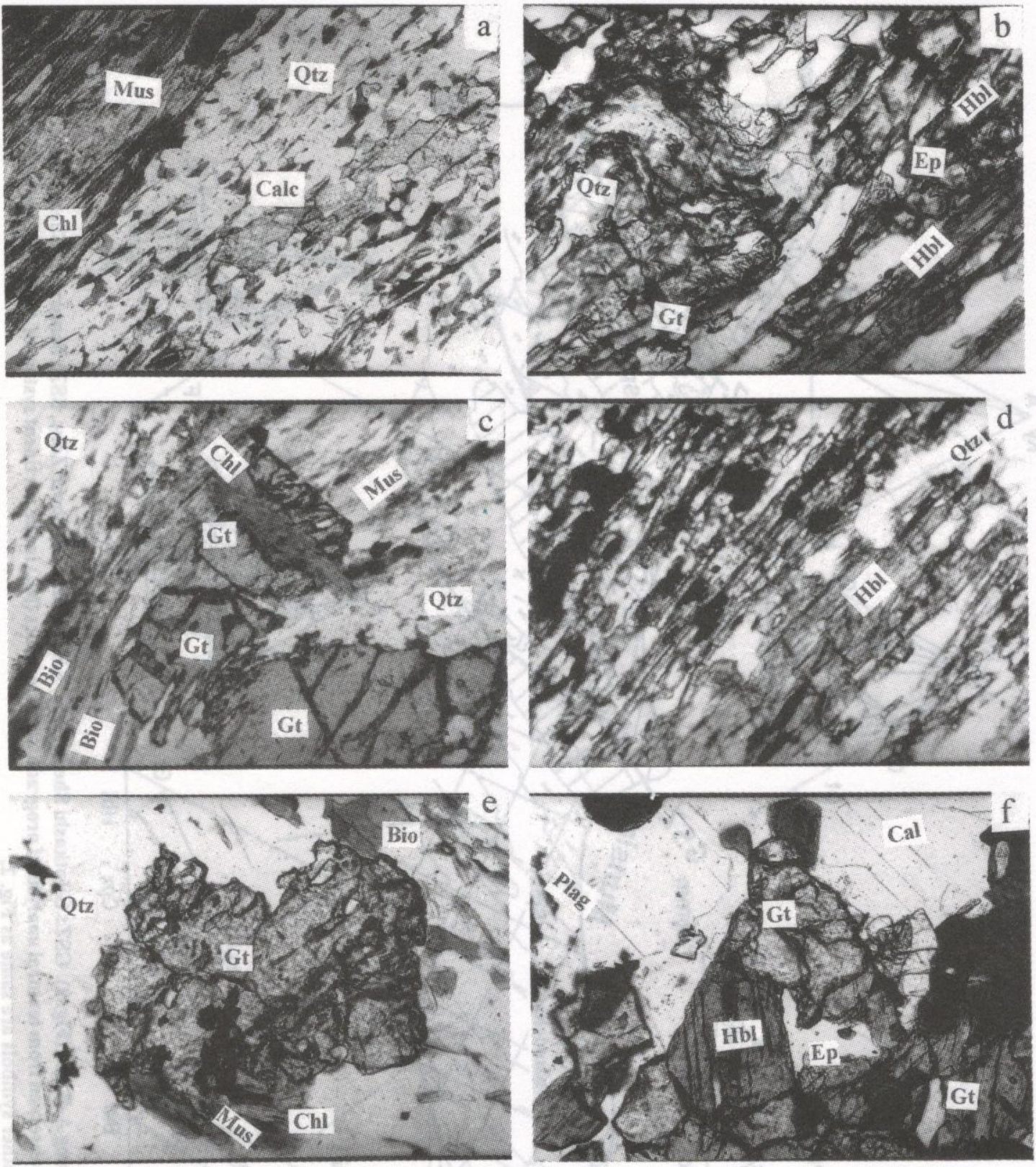

Fig. 4: (a) Low grade metamorphic assemblages define the crystallisation of chlorite (Chl), calcite (Calc), muscovite (Mus) and quartz (Qtz) on $\mathrm{S}_{1}$ foliation plane from the Guptkashi splay (1 Km north of Guptkashi). 40X, PPL, (b) Growth of garnet (Gt), from metabasics of Kalimath splay. 40X, PPL, (c) Coarse grained garnet (Gt) related to syn to post-tectonic crystallisation from garnet zone of Kalimath splay. 40X, PPL, (d) Coarse grained cummingtonite, hornblende $(\mathrm{Hbl})$, magnetite, quartz $(\mathrm{Qtz})$, crystallisation on $\mathrm{S}_{2}$ plain from Kalimath splay related to amphibolite facies conditions. PPL, (e) garnet (Gt), kyanite (Ky), biotite (Bio), muscovite (Mus) assemblages from Kyanite zone of amphibolite facies (from Kalimath splay). Chlorite (Chl) appeared due to retrogression. 40X, PPL, (f) calcite (Cal), plagioclase (Plag), garnet (Gt), hornblende (Hbl), epidote (Ep) texture from basic rocks related to Kyanite zone of Kalimath splay. 40X, PPL 
reactant and product phases defined by the reaction (2) in KFMASH system for garnet isograd are present. The wide range of occurrence of garnetchlorite-biotite assemblage indicates the divariant nature of this reaction.

$$
\mathrm{Chl}+\mathrm{Mus}+\mathrm{Qtz}=\mathrm{Alm}+\mathrm{Bio}+\mathrm{H}_{2} \mathrm{O}
$$

Besides the above texture equilibrium, the following reaction textures have also been observed for the crystallisation of garnet in the pelitic rocks.

$$
\begin{aligned}
& \mathrm{Fe}-\mathrm{Chl}+\mathrm{Qtz}=\mathrm{Alm}+\mathrm{Mt}+\mathrm{H}_{2} \mathrm{O} \\
& \mathrm{Chl}+\mathrm{Qtz}=\mathrm{Alm}+\mathrm{Chl}+\mathrm{Bio}+\mathrm{H}_{2} \mathrm{O}
\end{aligned}
$$

The basic rocks of this zone associated with metapelites contain hornblende, actinolite, epidote and plagioclase minerals on the $S_{1}$ foliation plane. The presence of actinolite-hornblende-chlorite and hornblende-epidote-chlorite (Fig. 4f) from this zone can be defined by the following reaction in the CFMASH system as shown in the ACF diagram.

$$
\begin{aligned}
& \mathrm{Act}+\mathrm{Ep}+\mathrm{Chl}=\mathrm{Hbl}+\mathrm{Qtz} \\
& \mathrm{Act}+\mathrm{Ep}+\mathrm{Chl}=\mathrm{Hbl}+\mathrm{Bio}
\end{aligned}
$$

\section{Kyanite-Staurolite Zone}

The presence of garnet-kyanite-muscovite-biotite (Gt-Ky-Mus-Bio) assemblage (Fig. 4e) from few pelitic bands of quartzites exposed at the eastern part may be considered to represent the beginning of the amphibolite facies. Unfortunately, alternate bands of the arenaceous and subordinate amount of argilloarenaceous rocks with low $\mathrm{FeO}$ and $\mathrm{Al}_{2} \mathrm{O}_{3}$ compositions are present in this zone. Therefore, the zone contains only quartzofeldspathic schist and gneisses, and staurolite bearing assemblages are rare. Sinha and Bisht (1986) have obtained the staurolite mineral from the rocks of the adjoining areas.

Typical assemblages of amphibolite facies, viz. garnet-hornblende-plagioclase-quartz (Fig. 4f), commingtonite-hornblende-magnetite-quartz (Fig. 4d) have been observed in the basic rocks. The appearance of garnet in the metabasics (Fig. 4f) can be defined by the following reaction in CFMASH system.

$$
\mathrm{Hbl}+\mathrm{Ep}+\mathrm{Chl}=\mathrm{Gt}+\mathrm{V}
$$

All the observed parageneses of this zone (Fig. 3) are related to the transition phase of greenschist and amphibolite facies. So it can be proposed that some parts of this unit were metamorphosed under the amphibolite facies conditions.

A thick shear zone (100-200 m) exposed at the base of this splay records the texture of retrograde metamorphism. The presence of andalusite-chloritebiotite-quartz on the shear plane of kyanitemuscovite-biotite-quartz bearing rock of amphibolite facies points to the fact that the shearing and retrograde metamorphism $\left(\mathrm{M}_{2}\right)$ possibly started during the late $\mathrm{D}_{3}$ deformation, and was subsequent to the completion of the $M_{1}$ episode of crystallisation and $\mathrm{D}_{2}$ deformation. As a result, the earlier formed garnet (Fig. 4c and 5c) either rotated or fractured, and different kinds of pressure shadow zones comprising chlorite-andalusite-biotite-sericite bearing assemblages developed along the shears in the rocks of amphibolite facies.

\section{Sonprayag Splay}

This splay zone includes porphyritic grey granitoid, augen-gneiss, migmatite, quartzofeldspathic schist, garnetiferous gneiss, sillimanite gneiss and enclaves of pelitic and calc-silicate within granitoid. The observed minerals of the different units are represented in the AFM diagrams (Fig. 3). The field relationships reveal that some of the rocks were once in the high grade metamorphism (Fig. 5a), characterised by partial melting and anatexis. The study of the enclaves of metasediments, and the intermingled relationship of granite with gneisses suggests that granitoids were emplaced in the amphibolite facies conditions. The location of the quartzofeldspathic gneisses and schists as the main components at the deeper position did not permit the formation of granitic melt. Not only this, the inadequate bulk composition $\left(\mathrm{K}_{2} \mathrm{O}, \mathrm{Na}_{2} \mathrm{O}\right.$, $\mathrm{FeO}+\mathrm{MgO}$ ) of such rocks prevented to develop the significant amount of garnet, kyanite, sillimanite and biotite minerals. There are three type of shears in this splay.

\section{Zone of Ductile Shears}

These are usually 25 to $50 \mathrm{~m}$ thick and are confined near the base of this splay. The zone contains recrystallised feldspar, biotite and muscovite along the shear. Some shear zones also 

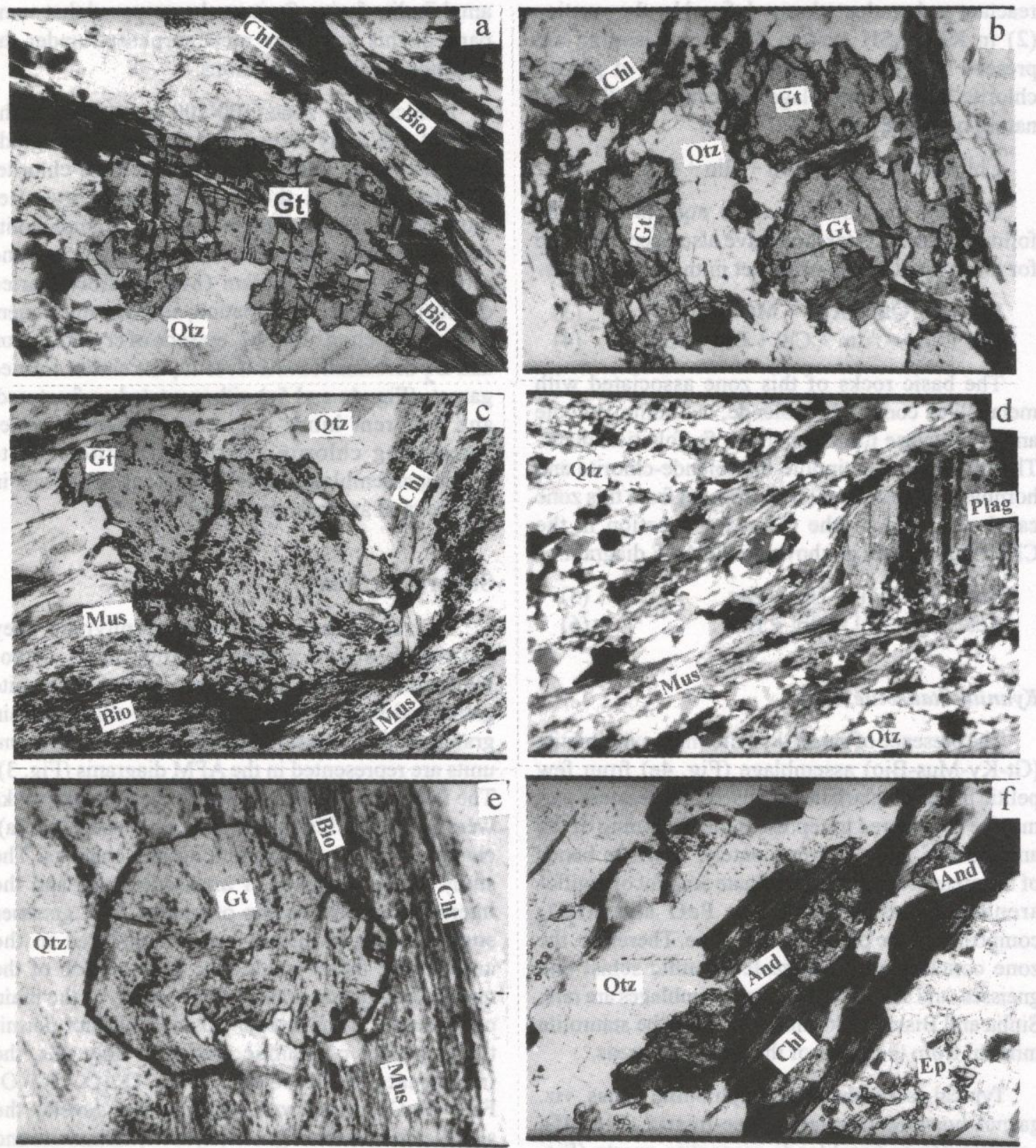

Fig. 5: (a) Fractured garnet (Gt), biotite (Bio), coarse grained $\mathrm{K}$-feldspar associated from garnetiferous gneisses of Sonprayag splay. Mineral biotite (Bio), muscovite (Mus), chlorite (Chl) and quartz (Qtz) define the sheared plain . 40X, PPL, (b) Highly fractured garnet (Gt), retrogrades into chlorite (Chl) from sheared zone during $\mathrm{D}_{3}$ deformation. 40X, PPL, (c) Pre-tectonic garnet (Gt) of $M_{1}$ episode from garnet zone under brittle-ductile of Kalimath splay. 40X, PPL, (d) Ductile-brittle texture from granite-gneisses of Kundchatti shear zone. 40X, PPL, (e) Ideoblastic post-tectonic garnet $(\mathrm{Gt})(\mathrm{Se} / \mathrm{Si})$ from shear zone related to $\mathrm{M}_{2}$ zone of metamorphism. 40X, PPL, (f) andalusite (And), chlorite $(\mathrm{Chl})$, muscovite from shear zone of granite-gneisses of Kundchatti splay related to $M_{2}$ metamorphism. Scale bar $=200 \mathrm{~mm}$, PPL. 


\section{Metamorphism and thrust tectonics in Munsiari Group of CCZ of Garhwal Himalaya, India}

contain a rim of low anorthite plagioclase, $\mathrm{K}$-feldspar around sericitised feldspar. The flame perthites and myrmekitic growth were also noticed. Chlorite and coarse grained muscovite are completely absent in such shear zone.

\section{Zone of Brittle-Ductile Shears}

It is 50 to $100 \mathrm{~m}$ thick and is close to the ductile shear in the field. This zone is characterised by mica fish type of structure. The chlorite and sericite bearing assemblages are rare, but muscovite proportion is high. The tiny crystal of the tourmaline, apatite, zircon, greenish and altered biotite are frequent.

\section{Zone of Late Stage Shears}

10 to $15 \mathrm{~m}$ thick and are most common in the Sonprayag shear zone. This zone is characterised by the abundance of chlorite, sericite, tourmaline, apatite, ilemeno-hematite and base metals. The quartz mineral shows an almond shaped lensoidal structure. The feldspars are highly fractured, and altered. The chlorite is coarse grained. The andalusite-sericite-chlorite paragenesis is very common along these shear zones.

\section{EVOLUTION OF THE METAMORPHISM AND DEFORMATION}

The morphology, degree of orientation and internal fabrics of the metamorphic minerals support that the metamorphism $\left(\mathrm{M}_{1}\right)$ in the Munsiari Group was mainly a syntectonic event of $\mathrm{D}_{1}$ and $\mathrm{D}_{2}$ (Fig. 4). This wide distribution of index mineral in each splay/duplex points to regional metamorphism in space and time, too. The internal fabrics with different styles, in the core of the garnet from rock of green schist facies (Fig. $4 b, 5 b$ and $5 c$ ) point out that minerals of the amphibolite facies initiated crystallisation at $\mathrm{D}_{1}$ and continued to the $\mathrm{D}_{2}$ deformation. The presence of augen-gneisses, migmatites, streaky gneisses, occurring at the displaced position in the investigated area were once at a time crystallized at the late stage of the $D_{2}$ deformation of the $M_{1}$ episode.
The texture also suggests that the garnet, cummingtonite, kyanite and sillimanite crystallised during a static phase between $\mathrm{D}_{1}$ and $\mathrm{D}_{2}$ followed by the feldspathisation in the late $\mathrm{D}_{2}$ phase. The assemblages commingtonite-hornblende-magnetitequartz, garnet-calcite-hornblende-plagioclasequartz, garnet-kyanite-biotite-muscovite-quartz, garnet-muscovite-biotite-quartz-Kfeldspar suggest the rocks of the investigated area were metamorphosed upto amphibolite facies conditions during the $\mathrm{M}_{1}$ episode. The evidence of the absence of hornfelsic texture around porphyritic granitoids and presence of enclaves of the metasediments of the amphibolite within the granitoids, suggest that granite were emplaced at a stage more or less contemporaneous to the advance stage of first episode of metamorphism and deformation $\left(D_{2}\right)$. The geochronological data reveals the $1850 \pm 50 \mathrm{Ma}$ age (Trivedi et al., 1984; Bhattacharya et al., 1984 and Singh et al., 1986) for the oldest unmetamorphosed granitoids. Therefore, this age may be considered for the $M_{1}$ episode of metamorphism.

The development of the andalusite-chloritemuscovite assemblages along the shear planes of the kyanite-muscovite-biotite schists and also along granite-gneisses (amphibolite facies) points out that S-C fabrics were developed after crystallisation of the $\mathrm{M}_{1}$ episode. Similarly, different assemblages, viz. chlorite-muscovite-quartz in the other shear zones, point the different type of S-C fabric development in the subsequent events. The ultramylonite to mylonite textures (Fig. 5d) from granitoids and gneisses show absence of the chlorite and muscovite minerals. The biotite-garnet-plagioclase (An 30-40)perthite-quartz assemblages on the schistosity $\mathrm{S}_{2}$ as well as shear plane (Fig. 5a) with the degradation in the size by dynamic recrystallisation, reveal that some shearing processes were acting at greater depths.

Subsequent to the ductile stage, the muscovitebiotite with chlorite with or without myrmekite, flame perthite, low anorthite of plagioclase, mica fish minerals were developed on the shear plane. The second type of shears commonly contains significant amount of muscovite, biotite, flame perthite, mortar texture and subordinate amount of chlorite, tourmaline, garnet, mica fish, etc. The grains are elongate, coarse in size, and occasionally contain 
thick S-C fabrics. The metamorphic and textural studies suggest $400-500^{\circ} \mathrm{C} / 5-6 \mathrm{kbar} \mathrm{P}-\mathrm{T}$ conditions at the time of these shearing.

The third type of shears of the granitoids comprise an abundance of chlorite, apatite, tourmaline, sericite, altered biotite, and ribbon shaped quartz. The presence of the chlorite-sericitebiotite assemblages along with microcline and albite suggests that $\mathrm{P}-\mathrm{T}$ conditions were possibly around $300-350^{\circ} \mathrm{C} / 3-4 \mathrm{kbar}$ pressure. In a few shears of granitoids, andalusite with sericite and biotite minerals were noticed which also support the above view (Fig. $5 f$ ). It should be mentioned here that at some places prograde idioblastic garnet is present (Fig. 5e). This texture suggests that possibly prograde metamorphism in the static phase existed during the shearing processes or MCT development.

The scattered geochronological data of minerals and whole rocks from the sheared zones of the $\mathrm{CCZ}$ (Sinha and Bisht, 1986 and Sorkhabi and Stump, 1993) range from 50 to $10 \mathrm{Ma}$. It is established that the MCT became active probably around $35 \mathrm{Ma}$ and ductile shear zones around $20 \mathrm{Ma}$ (Searl et al., 1988) and was uplifted in different stages (Valdiya, 1980 and 1987). So, the presence of widely distributed cooling ages from different shears may be incorporated with polyphase uplifting history (Fig. 6).

\section{CONCLUSIONS}

The Munsiari Group is represented by granitoids, gneisses along with metamorphics and characterised by different shear zones. The tectonic history reveals that subsequent to the $M_{1}$ metamorphism during the $\mathrm{D}_{1}$ and $\mathrm{D}_{2}$ deformations. The rocks of Precambrian age were subjected to metamorphism during the Tertiary crustal shortening. As a result, different shear zones developed in the $\mathrm{CCZ}$ of the $\mathrm{M}_{1}$ episode at a depth of about $20 \mathrm{~km}$. Due to continuous uplifting under the brittle-ductile conditions (marked by various assemblages) different dislocation planes were formed within the Munsiari Group. The low grade rocks displayed by the Guptakashi splay was overthrust on the Kundchatti splay. In subsequent stage of shortening, the medium-grade rocks of the Kalimath splay were overthrust on the Guptakashi splay. Thus, a polyphase ramping due to consistent

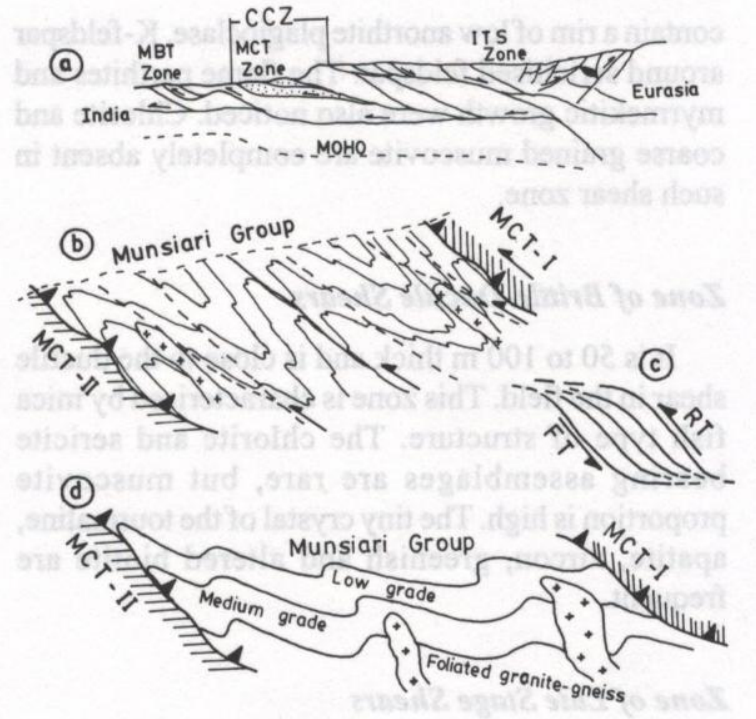

Fig. 6: (a) General model of tectonic evolution of the Himalaya (Hodges et al., 1988), (b) Crustal shortening and shearing in the Munsiari Group during late Tertiary deformation, (c) Duplex mechanism model proposed for shearing and thrusting in the different splays. RT: Roof Thrust; FT: Floor Thrust and (d) Probable metamorphic sequence in the early stage of Tertiary deformation which subsequently subjected to intensive deformation.

crustal shortening produced the imbricate thrust geometry in the Munsiari Group subsequent to development of the composite Main Central Thrust.

\section{ACKNOWLEDGEMENT}

Authors are thankful to Professor Zulfikar Ahmed, Institute of Geology, University of Punjab, Pakistan for his constructive comments on the paper.

\section{REFERENCES}

Bhattacharya, A.K., Bhatnagar, G.S., Narayan Das, G.R., Gupta, J.N., Chabria, T. Bhalla, N.S., 1984, Rb/Sr dating and geological interpretation of sheared granitegneiss of Brijranigad, Indegnala, Bhilangana valley, Tehri district, U.P. Him. Geol., v. 12, pp. 212-224.

Das, B.K. and Pande, I.C., 1973, Zone of progressive regional metamorphism in Dhudatoli syncline, Garhwal Himalaya. Him. Geol., v. 3, pp. 190-208. 


\section{Metamorphism and thrust tectonics in Munsiari Group of CCZ of Garhwal Himalaya, India}

Fuchs, G. and Sinha, A.K., 1978, The tectonics of the Garhwal-Kumaun Lesser Himalaya. Jb. Geol. B.A., v. 121 , pp. $219-241$.

Gansser, A., 1981, The geodynamic history of Himalaya. In: Gupta, H.K. and Delany, F.M. (eds), ZagrosHindukush-Himalaya geodynamic evolution, Am. Geophy. Union Geodyn. Ser., v. 3, pp. 111-121.

Gupta, L.N., 1987, Geology of Mandi-Pandoh areas with special reference to Chail metamorphites and granite rocks, district Mandi. In: V.K. Gairola (ed.), Proc. National Seminar on Tertiary in Indian Subcontinent, pp. 229-248.

Heim, A. and Gansser, A., 1939, Central Himalaya, geological observations of the Swiss expedition 1936. Mem. Soc. Helv. Sci. Nat., v. 73, pp. 245.

Hodges, K.V. Hubbard, M.S. and Silverberg, D.S., 1988, Metamorphic constrains on the thermal evolution of central Himalaya orogen. Phil. Trans. Roy. Soc. Lond., A 326, pp. 257-280.

Islam, R. and Thakur, V.C., 1988, Metamorphic history of Bhilangana valley, Garhwal Himalaya. Pub. Cent. Adv. Stud. Geol., P.U., Chandigarh, v. 3, pp. 127-138.

Janpangi, B.S. and Phukan, C.N., 1975, Geology of Okhimath area with special reference to the Main Central Thrust. Geol. Surv. Ind., Misc. Pub. 24, pp. 128-140.

Kumar, G. and Agarwal, N.C., 1975, Geology of SrinagarNandprayag area, Alaknanda Valley, Chamoli, Garhwal and Tehri Garhwal districts, Kumaun Himalaya, U.P. Him. Geol. v. 5, pp. 29-59.

Le Fort, P., Deobon, F. Pecher, A. Sonet, J. and Vidal, P., 1986, The 500 Ma magnetic event in Alpine southern Asia episode at Gondwana scale. Sci. de la Terre, Mem., v. 47, pp. 191-209.

Metcalfe, R.P., 1993, Pressure, temperature and time constraints on metamorphism across the Main Central Thrust zone and High Himalayan Slab in the Garhwal Himalaya. In: P.J. Treloar and M.P. Searle (eds), Himalayan Tectonics, Geol. Soc. Spec. Publ. No. 74, pp. 485-509.

Ravishankar, Kumar, G. and Singh, G., 1995, Sequence stratigraphy and major geological events of Himalaya. In Symp. on recent advances in geological studies of NW Himalaya and the Foredeep. Spec. paper, Geol. Surv. India, Lucknow.

Rawat, R.S. and Varadrajan, S., 1979, Alaknanda Thrust. Curr. Sc., v. 48 , pp. $864-865$.

Saklani, P.S., 1993, Geology of Lower Himalaya (Garhwal). International Books and Periodicals, Delhi, $246 \mathrm{p}$.

Searl, M.P., Cooper, D.J.W. and Rex, A.J., 1988, Collision tectonics of the Ladakh-Zansker Himalaya. Phil. Trans. R. Soc. Lond. A 326, pp. 117-150.
Singh, R.P., Singh, V.P., Bhanot, V.B. and Mehta, P.K., 1986, Rb-Sr ages of the gneiss rocks of RiheeGangi, Bhatwari, Hanumanchatti and Naitwar areas of the Central Crystalline Zone of Kumaon Himalaya (U.P.). Ind. Jour. Earth Sc., v. 13, pp. 197-208.

Singh, V.K., Singh, S.P. and Saklani, P.S., 1994, Kyanite-sillimanite-andalusite-bearing schist from Central Crystallines of Budhakedar area, Garhwal Himalaya. Bull. Ind. Geol. Assoc., Chandigarh., v. 27, pp. 143-153.

Singh, V.K., Singh, S.P. and Saklani, P.S., 1996, Metamorphic and geodynamic evolution of Garhwal Himalaya, India. N. Jb. Geo. Palaonl. Abh., v. 199, pp. 89-109.

Singh, S.P., Singh, V.K. and Saklani, P.S., 1997, Metamorphic evolution of the Central Crystallines of Higher Himalaya along Dhauliganga valley, Garhwal Himalaya, India. N. Jb. Geol. Palaont. Abh., v. 206, pp. 249-275.

Sinha, A.K., 1989, Geology of Higher Central Himalaya. John Wiley and Sons., 219 p.

Sinha, A.K. and Bisht, K.S., 1986, K-Ar dating of the crystalline and basic rocks from Garhwal Central Himalaya. Ind. Jour. Earth Sc., v. 13, pp. 209-215.

Sorkhabhi, R.B. and Stump, E., 1993, Rise of the Himalaya: a geochronologic approach. GSA Today, v. 3, pp. 87-92.

Srivastava, R.N. and Ahmad, A., 1979, Geology and structure of Alaknanda-valley, Garhwal Himalaya. Him. Geol., v. 9, pp. 225-254.

Thakur, V.C., 1992, Geology of Western Himalaya. Pergamon press, London, $355 \mathrm{p}$.

Trivedi, J.R., Gopalan, K. and Valdiya, K.S., 1984, Rb-Sr. age of granitic rocks with in the Lesser Himalayan nappe, Kumaun, India. Jour. Geol. Soc. Ind., v. 25, pp. 641-654.

Valdiya, K.S., 1980, Geology of Kumaun Lesser Himalaya. Wadia Inst. Him. Geol., Dehradun, 219 p.

Valdiya, K.S., 1981, Tectonics of the central sector of the Himalaya. In: Gupta, H.K. and Delany, F.M. (eds), Zagros-Hindukush-Himalaya geodynamic evolution. Am. Geophy. Union Geodyn. Ser., v. 3, pp. 87-110.

Valdiya, K.S., 1987, Trans-Himadri Thrust and domal upwarps immediately south of collision zone and tectonic implications. Curr, Sc. v. 56, pp. 200-209.

Valdiya, K.S. and Goel, O.P., 1983, Lithological subdivision and petrological of the great Himalaya Vaikrita Group in Kumaun, India. Proc. Earth and Planet Sc., v. 92, pp 141-163. 